\title{
AYURLOG
}

National Journal of Research in Ayurved Science

http://www.ayurlog.com

January-March: 2021| Volume: 09th $\mid$ Issue:1 ${ }^{\text {st }}$

ISSN: 2320-7329

\section{"Role of karnapurana kriya in various symptoms of karnarogas with special reference to continuous use of headphones- a review."}

\author{
Komal K Sharma*1, Mohan B Yeole ${ }^{2}$, Govind D. Tundalwar ${ }^{3}$.
}

1. PG Scholar,

2. HOD and Professor,

3. Associate Professor

Shalakyatantra Department, Shri Ayurved Mahavidyalaya, Nagpur, Maharashtra

*Corresponding author: komalsharma2550@gmail.com

\begin{abstract}
Background- Irrational use of electronic sound conductor as head phones, smart phones overuse causes sound pollution which affects the ear. In some extant Apathyakara Ahara Viharalsolso lead in development of different Karnarogas. Objectives- To analyses the role of KarnapuranaKriya in different karnarogas due to continuous use of headphones. Result and Discussion-Karnapuranakriya is better act on different symptoms of karnarogas like headache, vertigo, karnashushkta and karnanada. There are differenttailas are available in Ayurveda for karnapuranakriya like Tilataila, Sarshpataila, Bilvataila etc. These tailas are easily availableand cheap conservative line of treatment for different Karnarogas.
\end{abstract}

\section{KEYWORDS: Karnapurana,}

Karnendriya, Karnarogas, Headphones, Tailas.

\section{INTRODUCTION}

Shalakyatantra is a part of Ayurveda which deals with disease of sense organs. Shravanendriya is one among the five sense organs and its Adhisthana is known as Srotra. In Ayurvedic literature the Karna is the seat of Shravanendriya, the functional aspect of aspect of hearing. The main function of ear is the perception of sound, along with function of hearing. It maintain the equilibrium of body. Now a days there is a lot of change in the lifestyles of people. Generally people pay attention to different food habits and way of living. Due to growth of population, number of vehicles have increased which result in air and sound pollution which affects the ear. In some extant Apathyakara Ahara Vihara also leads in development of different types of Karnarogas $^{[1]}$

Acharya Sushruta described 28 Karnarogas in Sushruta Samhita ${ }^{[2]}$ According to modern 
science due to excess exercise in terms of times and intensity of sound on ear i.e. Atiyoga of Karnendriya vertigo, headache, Karnashushkta, Karnanada, tinnitus are mostly seen in many patients. These symptoms are commonly found in younger's because of continuous use of electronic sound conductor like headphones. These Vihara causes above symptoms may lead to less hearing sense in younger which will affect physical and mental health. So it is necessary to treat properly. In modern practice these disease are treated by systemic as well as local analgesics or steroids and anti-inflammatory drugs. But recurrence is common. So it need to better treatment. Karna has the predominance of Akasha Mahabhuta along with other Bhutas in similar properties. All the Karnarogas are mainly due to vitiation of Vata. ${ }^{[3]}$

\section{AIMS AND OBJECTIVES}

- To evaluate the effect of Karnapurana in various symptoms of Karnarogas with special reference to continuous use of headphones.

- Evaluate prevention aspect of Karnarogas due to continuous use of headphones.

\section{MATERIALS AND METHODS}

Acharya Charaka and Acharya Vagbhata advocate that Karnapurana should be done daily to avoid the diseases of the ear. Acharya Sushruta also has mentioned Karnapurana in Swasthavrittiya Adhyaya. Karnapurana is a complete solutionfor any kind of ear problems and it really a unique treatment of Ayurveda.
Definition- Karnapurana is the process of filing the Swarasa, Taila etc, into ear to cure different disease affecting ear, neck and head.

Types- classified according to use ${ }^{[4]}$

1. As daily procedure

2. In pathological condition

Procedure- Whole procedure can be broadly divided into three parts ${ }^{[5]}$

\section{PurvaKarma-}

- Person should be made to lie down on lateral side and hand of that side should be beneath head and other hand should be resting on trunk of that side.

- Gently massage should be done with lukewarm medicated oil around the ear and pinna for a short duration of time. Massage should also cover lateral portion of neck inferior to ear.

- After this heat is applied around ear with towel soaked in boiling water by waving, touching and pressing for some time.

\section{Pradhana Karma-}

- The medicated oil should be heated in water bath to make lukewarm.

- The external auditory canal should be straightened by pulling the pinna backward, and upwards.

- The oil should be poured in drops till the ear canal is filled up to the base of concha.

- The root of ear should be gently massaged in order to potentiate the action of the drug. 
- The medicated oil should be retained in same position for prescribed time limit.

\section{Pashchata Karma-}

- The excess oil should be taken out of the external auditory canal by dry cotton.

- After retaining the medicated oil for the prescribed time, the ear should be cleaned with dry cotton mopping.

- The same procedure should be repeated in the fellow ear also.

Dosage- Quantity of dravya not mentioned specifically but it should be the quantity which fills the external auditory canal without overflowing.

Duration- ${ }^{[7]}$

In Karnarogas- 100 Matra

In Kantharogas- 500 Matra

In Shiroroga- 1000 Matra

In painful condition- till pain relives

In Swastha- 100 Matra

\section{Benefits of Kanapurana ${ }^{[8]}$}

- Medicated oils are used in Karnapurana. Those oils have strengthening properties of ear structure. Those oils nourish all parts of ear including external ear, middle ear, inner ear and eardrum.

- It is very helpful for balance disorders. Balance disorder is characterized by vertigo, dizziness and loss of balance.

- In earache it is good therapy. The Ayurvedic oils used in Karnpurana are beneficial for reducing inflammation and pain of the ear.

- Karnapurana also improves hearing capacity and quality. It nourishes acoustic nerve and improves signal quality to the brain.

- The mind disturbs due to many reasons such as depression, sleeplessness, emotional trauma etc. Karnapurana helps to calm the brain and mind as well.

- It increase sense of sound by enhancing ear function.

- If Karnapurana taken regularly in interval of six months, it helps to prevent frequent ear infections.

- Karnapurana helps in headache and migraine that are associated with body balance problems.

\section{Contraindications ${ }^{[9]}$}

Karnapurana is contraindicated in eardrum rupture, ear injury, cuts in the skin of ear, burns that affects ears.

\section{Discussion-}

Karna is one of the most important sense organ. Its important function is hearing. It is also important organ in maintaining balance of body. The common symptoms produced by Atiyoga of Karnendriya causes inconvenience to the patient in daily routine. So it is necessary to have very effective treatment without side effect and economical drug on it.

Various antibiotics and anti-inflammatory drugs are used, but there effect is found to be less. After study it is observed that the patients having the habits of exposure to noise pollution and excessive head phone users are more prone to this disease. 


\section{CONCLUSION}

Various Aushadhi Siddha Tailas mentioned in Samhitas better acts on different symptoms of Karnarogas like headache, vertigo, Karnashushkata, Karnanada. People who exposed to noise pollution and excessive headphone users are more prone to this disease. These Tailas used for longer duration may prove more effective. These Tailas is easily available and cheap conservative line of treatment for Karnarogas.

\section{REFERENCES}

1. CharakaSamhita (Shri Satya Narayan Shastri)Chaukhambha Bharti Academy Varanasi.

2. KavirajaAmbikaduttaShastri; SushrutaSamhita of MaharsiSusruta with the Ayurveda tattvaSandipikahindi Commentary; Chaukhambha Sanskrit Sansthan Varanasi, reprint 2013; Uttartantra 20 pg. no. 111.

3. Vagbhata, AshtangaHridaya edited by Dr. Kunte\&Navare, $9^{\text {th }}$ edition, ChaukhambaOrientalia, Varanasi, 2005.
4. Illustrated SushrutaSamhita commentary by Prof.K.R.Shrikanta Murthy, Chikitsasthana chapter 2/9 Published by ChaukhambhaOrientalia Varanasi Edition 2013 page no.24.

5. Smt. ShailajaShrivastava, SharanghdharSamhita, Uttarkhand chapter 11/128 Published by ChaukhambhaOrientalia Varanasi Edition 2009 Page.no.450.

6. Vagbhata, AshtangaHridayam commentary by Prof.K.R.Shrikanta Murthy, Sutra sthana chapter 22/32 Published by ChaukhambhaKrishnadas Academy Varanasi Edition 2013 Page.no 22.

7. Shri LakshmipatiShastri, YogratnakaraUttarardhgata chapter KarnaRogadhikara Published by Chaukhambha Publication Varanasi Edition 2013 Page.no.309.

8. Vaidya Haridas Shreedhar KastureAyurvediyaPanchkarmaVigh yanKasture Chapter 2 SnehaVighyan Published By Shri BaidyanathAyurvedBhawanIlhabad, Edition 2015 Page.no.100.

9. Http://everydayayurveda.org/karnapu rana.

Conflict of Interest: Non Source of funding: Nil

Cite this article:

"Role of karnapurana kriya in various symptoms of karnarogas with special reference to continuous use of headphones- a review."

Komal K Sharma, Mohan B Yeole, Govind D. Tundalwar Ayurlog: National Journal of Research in Ayurved Science- 2021; (09) (01):01-04 